\title{
HYGIENIC ASSESSMENT OF THE RISK OF GROUNDWWTEER CONTAMINATION WITH FUNGICIDES BASED ON DIMOXYSTROBIN
}

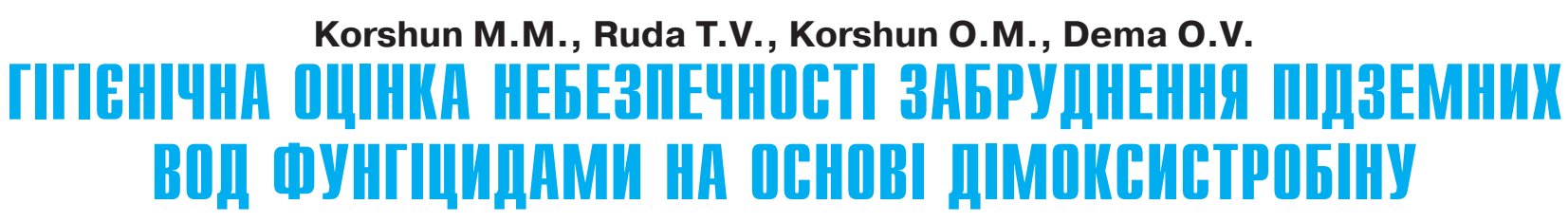

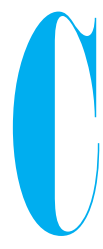

КОРШУН М.М., РУДА Т.В., КОРШУН О.М., ДЕМА О.В.

Національний медичний університет

ім. О.О. Богомольця, м. Київ

УДК $614.7: 628.1 .036$ :

632.952

Ключові слова: фунгіциди, дімоксистробін, забруднення підземних вод, порогова

концентрація, оцінка небезпечності. учасна сільськогосподарська практика невід'ємно пов'язана 3 використанням хімічних засобів захисту рослин [1]. Водночас хімізація сільського господарства $€$ однією з причин забруднення об'єктів довкілля, зокрема поверхневих і підземних водойм. Відомо, що забруднення джерел водопостачання пестицидами можливе не лише за рахунок їх надходження при застосуванні, але й у результаті змивання 3 поверхні ґрунту або вертикальної міграції за його профілем 3 подальшим потраплянням у підземні води [2]. Проблема забруднення ґрунтових вод $€$ актуальною на сьогодні і для урбанізованих територій, і для сільської місцевості, адже 80\% сільського населення України використовують ґрунтову воду як джерело децентралізованого (місцевого) водопостачання [3]. Зважаючи на це залишається актуальним питання наукової регламентації безпечних рівнів пестицидів у воді водойм та ґрунті. Особливої уваги з боку гігієністів потребують стійкі речовини, які здатні тривалий час зберігатися у довкіллі. До таких високостійких пестицидів належить дімоксистробін - діюча речовина (д.р.) комбінованого фунгіциду Піктор, концентрат суспензії (KC).

Препарат Піктор, КС (д.р. дімоксистробін, 200 г/л і боскалід, 200 г/л) виробництва Ф. БАСФ, Німеччина застосовують для боротьби з хворобами соняшника та ріпака у максимальній нормі витрат 0,5 л/га одноразово за вегетаційний сезон. Дімоксистробін належить до класу стробілуринів - квазісистемних фунгіцидів з трансламі-
ГИГИЕНИЧЕСКАЯ ОЦЕНКА ОПАСНОСТИ ЗАГРЯЗНЕНИЯ ПОДЗЕМНЫХ ВОД ФУНГИЦИДАМИ НА ОСНОВЕ ДИМОКСИСТРОБИНА

Коршун М.М., Рудая Т.В., Коршун О.М., Дема Е.В.

Национальный медицинский университет им. А.А. Богомольца, г. Киев

Целью исследования была оценка опасности загрязнения димоксистробином грунтовых вод на основании математического моделирования и экпериментального изучения закономерностей его вертикальной миграции в системе «почва грунтовые воды» и научное обоснование пороговой концентрации в почве по водно-миграционному показателю вредности для дальнейшей разработки предельно допустимой концентрации (ПДК) в почве. Материалы и методы. Прогноз опасности загрязнения подземных вод димоксистробином осуществлен на основании определения интегрального вектора опасности, исходя из индекса потенциального вымывания, периода полуразрушения вещества вследствие гидролиза и зоны биологического действия. При математическом моделировании процесса миграции димоксистробина из почвы в грунтовые воды использованы уравнения регрессии, описывающие зависимость гигиенического норматива в почве от ПДК в воде водоемов. Экспериментальное изучение вертикальной миграции димоксистробина проведено на 6 фильтрационных колонах конструкции акад. Е.И. Гончарука с использованием модельного почвенного эталона № 1 и чернозема выщелоченного. Исходные концентрации димоксистробина в верхнем (0,2 м) слое почвы составляли 0,05; 0, 1; 0,5 и 1,0 мг/кг. Отбор проб фильтрата на протяже- нии первых 30 суток проводили ежедневно, далее - каждые 5 суток. Димоксистробин в фильтрате определяли методом высокоэффективной жидкостной хроматографии с пределом количественного определения 0,001 мг/дм³. Результаты. Димоксистробин отличается низкой или средней мобильностью по величине коэффициента сорбции органическим углеродом, но высокой способностью к миграции из почвы в подземные воды по индексу потенциального вымывания (GUS). Рассчитанная по уравнениям регрессии ориентировочно допустимая концентрация (ОДК) димоксистробина в почве составила 0,04 мг/кг и была в 2 раза ниже утвержденной в Украине ОДК. Интегральный вектор опасности для здоровья населения вследствие загрязнения подземных вод димоксистробином (138,6 баллов) соответствует высокому уровню. Экспериментально установлено, что димоксистробин является чрезвычайно подвижным в системе “почва - грунтовые воды". Уровни миграции димоксистробина из почвы в фильтрат зависят от типа поверхностного пахотного слоя и исходных концентраций вещества.

Пороговая концентрация димоксистробина в почве по водно-миграционному показателю вредности установлена на уровне 0,05 мг/кг, что соответствует 1,5 максимальным нормам расхода. Поэтому использование препаратов на основе димоксистробина в максимальной рекомендованной норме расхода не приведет к загрязнению грунтовых вод в реальных почвенно-климатических условиях Украины.

Ключевые слова: фунгициды, димоксистробин, загрязнение подземных вод, пороговая концентрация, оценка опасности.

() Коршун М.М., Руда Т.В., Коршун О.М., Дема О.В. СТАТТЯ, 2016. 
нарною дією, механізм впливу яких на фітопатогени полягає в інгібуванні мітохондріального дихання за рахунок блокування переносу електронів між цитохромом $b$ і цитохромом $c$ у місці окислення убіхінолу, внаслідок чого спостерігається припинення вироблення енергії і загибель грибкових патогенів. Тобто механізм дії стробілуринових фунгіцидів спрямований на конкретну мішень, що відповідає новому стандарту у контролі над хворобами рослин [4].

В Україні для дімоксистробіну було затверджено допустиму добову дозу (ДДД)

0,005 мг/кг, гігієнічні нормативи в об'єктах довкілля, зокрема й орієнтовно допустима концентрація (ОДК) у ґрунті - 0,08 мг/кг, та аналітичні методи, які дозволяють контролювати їх дотримання (постанови державного санітарного лікаря № 9 від 29.02.2008, № 8 від 27.02.2010, № 23 від 05.12.2011).

Згідно 3 даними польових досліджень, які були проведені у країнах Європи, дімоксистробін виявляли у ґрунті протягом більше року [5], тому існує ймовірність збереження та накопичення його у поверхневих родючих шарах з подальшим надходженням до сільськогосподарських рослин та у ґрунтові води. Отже, згідно з існуючими в Україні підходами для мінімізації вторинного забруднення об'єктів довкілля внаслідок міграції із ґрунту у суміжні середовища та здійснення гігієнічного контролю над використанням препаратів на основі дімоксистробіну необхідно експериментально обґрунтувати його гранично допустиму концентрацію (ГДК) у ґрунті.

Враховуючи вищезазначене, метою роботи була оцінка небезпечності забруднення дімоксистробіном ґрунтових вод на підставі математичного моделювання та експериментального вивчення закономірностей його вертикальної міграції у системі «ґрунт - ґрунтові води» та наукове обґрунтування порогової концентрації у ґрунті за водно-міграційним показником шкідливості для подальшої розробки ГДК у ґрунті.

Матеріали та методи. Об'єктом дослідження був дімоксистробін - (Е)-2-(метоксиімін)-N-метил-2-а-(2,5-ксилилокси)-о-толіл] ацетамід. Його хімічна формула - $\mathrm{C}_{19} \mathrm{H}_{22} \mathrm{~N}_{2} \mathrm{O}_{3}$, молекулярна маса - 326,4 атомних одиниць маси.

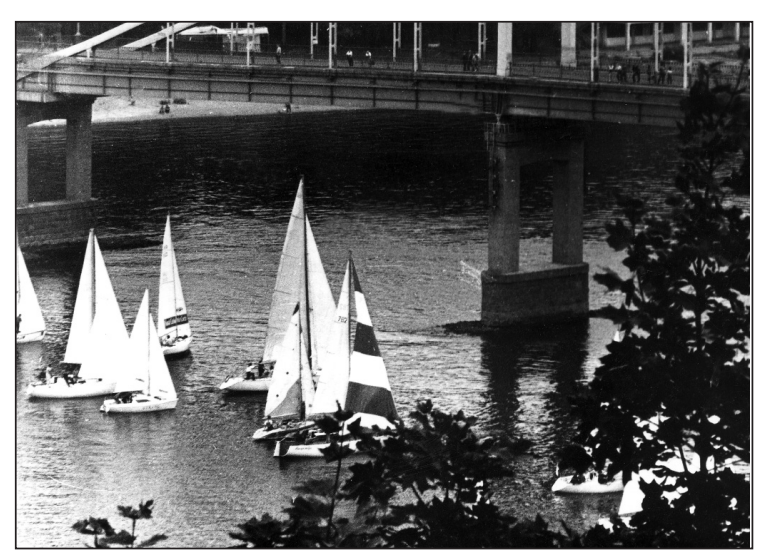

ФАКТОРИ ДОВКІЛЛЯ І ЗДОРОВ'Я

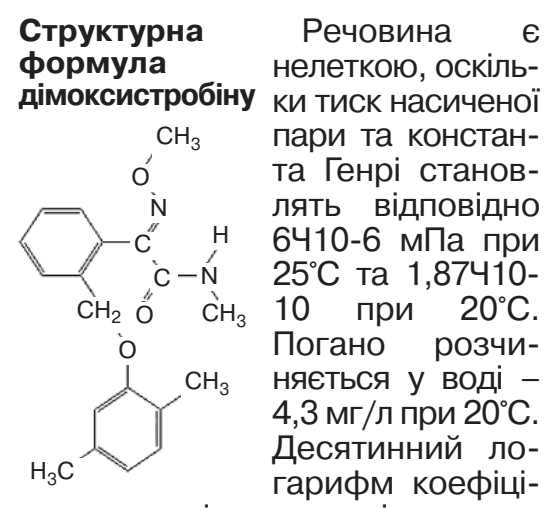
єнта розподілу у системі октанол вода $\left(\lg \mathrm{K}_{\mathrm{o} / \mathrm{w}}\right)$ становить 3,59 при $20^{\circ} \mathrm{C}[6]$.

Для досягнення поставленої мети проведено оцінку небезпечності забруднення ґрунтових вод згідно з [7-9], математичне моделювання та лабораторний експеримент з вивчення вертикальної міграції дімоксистробіну у системі «'рунт - ґрунтові води» відповідноі до [10-12].

Прогноз ризику забруднення підземних вод дімоксистробіном здійснено згідно з методикою Сергєєва С.Г. зі співавт. [9], яка передбачає визначення інтегрального вектора небезпечності $(R)$, виходячи з трьох критеріїв: індексу потенційного вимивання (Groundwater Ubiquity Score GUS), що характеризує можливість міграції речовин із ґрунту у підземні води; періоду напівруйнації $\left(\tau_{50}\right)$ речовини внаслідок гідролізу, що відображає тривалість забруднення води; зони біологічної дії ( $\left.Z_{\text {biol.ef. }}\right)$, що свідчить про токсичність і кумулятивність речовини.

Значення GUS i $\tau_{50}$ у воді наведено з даних літератури [5, 6]. Розрахунок зони біологічної дії $\left(Z_{\text {biol.ef. }}\right)$ здійснено за формулою:

$$
\mathbf{Z}_{\text {biol.ef. }}=\mathbf{L D}_{\mathbf{5 0}} / \mathbf{L i m}_{\mathbf{c h}} \text {, }
$$

де $L_{50}$ - середньосмертельна доза при одноразовому введенні у шлунок щурам, Lim ch $_{-}$ поріг хронічної дії при пероральному надходженні, які для дімоксистробіну становлять $>5000$ мг/кг та 4 мг/кг відповідно згідно 3 [5].
Інтегральній вектор небезпечності (R) розраховано за формулою:

$$
R=\sqrt{x^{2}+y^{2}+z^{2}},
$$

де $x, y, z$ - бальна оцінка індексу потенційного вимивання, періоду напівруйнації внаслідок гідролізу у воді та зони біологічної дії відповідно до [9].

При математичному моделюванні процесу міграції дімоксистробіну із ґрунту у ґрунтові води використано рівняння регресії, які запропоновано у $[13,14]$ для розрахунку ОДК пестициду у ґрунті, виходячи з ГДК у воді водойм (ГДК

$$
\begin{aligned}
& Y=0,24+2,49 \cdot Г Д К_{\text {в.в. }} \\
& Y=1,02+0,31 \cdot \lg \text { ГДК в.в. } \\
& \mathrm{Y}=2,28 \cdot \text { ГДК } \\
& \mathbf{Y}=\mathbf{0 , 5 6 8 + 0 , 0 8 4 \bullet \operatorname { l n } \text { ГДК }}
\end{aligned}
$$

де Ү - ОДК у ґрунті, мг/кг.

Експериментальне вивчення вертикальної міграції дімоксистробіну виконано на 6 фільтраційних колонах конструкції акад. Є.Г. Гончарука з висотою 1,05 м і площею поперечного перерізу 0,4х0,4 м кожна [10]. Нижню частину кожної колони завтовшки 0,8 м завантажували модельним ґрунтовим еталоном № 1 (МГЕ № 1), який $€$ сумішшю середньо- та дрібнозернистого річкового піску з мінімальною сорбційною і поглинальною та максимальною фільтраційною здатністю. Для створення екстремальних умов міграції верхні 0,2 м у двох колонах завантажували МГЕ № 1. В інших 4-х колонах верхній орний шар моделювали чорноземом вилуженим, оскільки чорноземи є найбільш поширеними ґрунтами в України і займають 27,8 млн. га, або 46\% іï території.

Дімоксистробін вносили і рівномірно розподіляли у верхньому $(0,2$ м) шарі ґрунту у кількостях, що відповідали 1,5; 3; 15 і 30 максимальним нормам витрат $(0,1$ кг д.р./га), тим самим створювали концентрації 0,05; 0,1; 0,5 і 1,0 мг/кг відповідно. 
Тривалість експерименту становила 70 діб. На кожну колону щоденно подавали воду у кількості 5 л зі швидкістю 3,5 мл/хв, що розраховували відповідно до [10], виходячи з максимальної для України середньорічної норми опадів 1000 мл. Відбір проб фільтрату протягом перших 30 діб проводили щоденно, надалі - кожні 5 діб. Підготовку проб фільтрату і кількісне визначення дімоксистробіну виконували згідно з [15]. Межа кількісного визначення дімоксистробіну у воді методом високоефективної рідинної хроматографії -

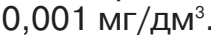

Результати та їх обговорення. Відомо, що процес міграції пестицидів у ґрунті, переміщення їх у системі «ґрунт - підземні води» $€$ результатом складної взаємодії низки факторів: фізико-хімічних властивостей речовини, характеристик ґрунту, кліматичних умов та регламентів застосування хімічних засобів захисту рослин [9, 10, 16]. Ймовірність потрапляння пестицидів у ґрунтові води зростає при збільшенні їхньої стійкості у ґрунті та воді та зменшенні сорбції компонентами ґрунту. Зокрема, у ґрунтах з низьким вмістом гумусу очікується підвищений ризик забруднення ґрунтових вод [16].

За даними літератури, у лабораторних експериментах $\tau_{50}$ дімоксистробіну у ґрунті залежно від ґрунтово-кліматичних умов становить 88-262 доби (у середньому 210) [6]. В аеробних умовах у ґрунтах 6 типів при $20^{\circ} \mathrm{C}$ та вологості на рівні $40 \%$ від повної вологоємності $\tau_{50}$ дімоксистробіну становить 88-401 доби. Основні його метаболіти, які утворюються у ґрунті, менш стабільні [5]. За нижчої температури у стерильному ґрунті, особливо в анаеробних умовах, руйнація дімоксистробіну уповільнюється. Так, в аеробних умовах при $5^{\circ} \mathrm{C} \tau_{50}$ становить 1203 доби, у стерильному ґрунті при $20^{\circ} \mathrm{C}-$ 733 доби, в анаеробних умовах при $20^{\circ} \mathrm{C}$ через 120 діб зберігалося 93,2\% вихідної кількості речовини [5]. Зазначене дозволяє віднести дімоксистробін за стабільністю у ґрунті до високостійких сполук (I клас небезпечності) згідно 3 [7].

у польових умовах у ґрунтах європейських країн $\tau_{50}$ дімоксистробіну становить 2-39 діб (у середньому 22,9) [6]. Зокрема у дослідженнях, проведених у Німеччині, Іспанії та Швеції, $\tau_{50}$ склав 16-39, 2-3 та 34 доби відповідно [5]. За 1 рік у ґрунтах перших двох країн залишилося 14,3-16,5\% вихідної кількості речовини, у Швеції - 44\%. Показано, що зникнення речовини із ґрунту спочатку відбувається доволі швидко $3 \tau_{50} 8-120$ діб, згодом уповільнюється, і період руйнації 90\% вихідної кількості речовини $\left(\tau_{90}\right)$ може перевищити 500 діб [5]. Тобто дімоксистробін у польових умовах зникає із ґрунту дещо швидше, ніж у лабораторних і може бути віднесеним залежно від ґрунтово-кліматичних умов не лише до високостійких (I клас) чи стійких (II клас), а й до помірно (III клас) або навіть малостійких (IV клас) сполук.

Дімоксистробін гідролітично та фотолітично стабільний: $\tau_{50}$ внаслідок гідролізу при рH 4-9 та $20^{\circ} \mathrm{C}$ і фотолізу при $\mathrm{pH} 7$ понад 30 діб [6]. У стерильних буферних розчинах з рН 5, 7 і 9 при $25^{\circ} \mathrm{C}$ дімоксистробін не руйнується протягом 30 діб [5]. Фотоліз помірно сприяє деградації дімоксистробіну у воді: $\tau_{50}$ за безперервного опромінення у

лабораторних умовах становить 64,8 діб (у стерильному буферному розчині з рН 7) та 14,1 доби (у воді із водойми) [5]. У 2-х системах «вода - осад» при інкубації у темряві при $20^{\circ} \mathrm{C} \tau_{50}$ дімоксистробіну в усій систем становить 302 та 520 діб. Зникнення із водної фази відбувається швидше внаслідок накопичення речовини в осаді: $\tau_{50}$ у воді - 15 і 27 діб, $\tau_{90}-136$ i >200 діб [5]. В аналогічному досліді просто неба $\tau_{50}$ у водній фаз становить 15,3 доби, в усій системі $\tau_{50}-26,9$ доби, $\tau_{90}-89,4$ доби [5]. Зазначене свідчить, що за критерієм «стабільність у воді» дімоксистробін належить до високостійких сполук (I клас небезпечності).

Дімоксистробін, залежно від типу ґрунту, середньо- або малорухомий згідно з [8], про що свідчить коефіцієнт сорбції, нормований на вміст органічного вуглецю $\left(\mathrm{K}_{\mathrm{oc}}\right), 195,8-935,3$ мл/г (у середньому 486,2) [5, 6]. Однак індекс потенційного вимивання (GUS) на рівні 3,05 [6] підтверджує високу ймовірність потрапляння речовини у

Таблиця 1

\section{Динаміка вмісту дімоксистробіну у фільтрат}

\begin{tabular}{|c|c|c|c|c|c|c|}
\hline \multirow{3}{*}{ 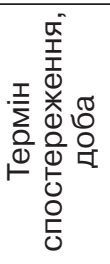 } & \multicolumn{6}{|c|}{$\begin{array}{c}\text { Концентрація* дімоксистробіну у фільтраті (мг/дм³) } \\
\text { залежно від виду та вихідної концентрації речовини у ґрунті } \\
\text { (мг/кг) }\end{array}$} \\
\hline & \multicolumn{2}{|c|}{ МГЕ № 1} & \multicolumn{4}{|c|}{ Чорнозем вилужений } \\
\hline & 0,05 & 0,1 & 0,05 & 0,1 & 0,5 & 1,0 \\
\hline 1 & H.B. ${ }^{\star \star}$ & H.B. & H.B. & H.B. & H.B. & H.B. \\
\hline 5 & H.B. & H.B. & H.B. & H.B. & H.B. & H.B. \\
\hline 7 & $<0,001$ & $<0,001$ & $<0,001$ & $<0,001$ & $<0,001$ & $<0,001$ \\
\hline 8 & 0,0015 & 0,0043 & $<0,001$ & 0,0017 & 0,0018 & 0,001 \\
\hline 10 & 0,0025 & 0,0100 & 0,0010 & 0,0056 & 0,0056 & 0,0089 \\
\hline 12 & 0,0030 & 0,0134 & 0,0019 & 0,0137 & 0,0106 & 0,0244 \\
\hline 14 & 0,0025 & 0,0180 & 0,0026 & 0,0115 & 0,0163 & 0,0475 \\
\hline 16 & 0,0017 & 0,0190 & 0,0015 & 0,0097 & 0,0132 & 0,0567 \\
\hline 20 & 0,0010 & 0,0225 & 0,0011 & 0,0090 & 0,0178 & 0,0661 \\
\hline 21 & 0,0010 & 0,0235 & 0,0010 & 0,0076 & 0,0228 & 0,0559 \\
\hline 23 & 0,0010 & 0,0177 & 0,0010 & 0,0073 & 0,0151 & 0,0486 \\
\hline 25 & $<0,001$ & 0,0160 & 0,0010 & 0,0074 & 0,0171 & 0,0527 \\
\hline 26 & - & 0,0142 & $<0,001$ & 0,0068 & 0,0165 & 0,0450 \\
\hline 29 & - & 0,0124 & - & 0,0057 & 0,0161 & 0,0455 \\
\hline 36 & - & 0,0094 & - & 0,0037 & 0,0171 & 0,0442 \\
\hline 39 & - & 0,0073 & - & 0,0032 & 0,0186 & 0,0257 \\
\hline 50 & - & 0,0051 & - & 0,0016 & 0,0155 & 0,0348 \\
\hline 60 & - & 0,0029 & - & - & 0,0134 & 0,0248 \\
\hline 70 & - & 0,0025 & - & - & 0,0111 & 0,0183 \\
\hline
\end{tabular}

Примітки: * - наведено середні значення з трьох визначень; ** - н.в. - не виявлено. 
5 days. Dimoxystrobin in the filtrate was determined

HYGIENIC ASSESSMENT OF THE RISK OF GROUNDWATER CONTAMINATION WITH FUNGICIDES BASED ON DIMOXYSTROBIN Korshun M.M., Ruda T.V., Korshun O.M., Dema O.V. A.A. Bohomolets National Medical University, Kyiv

Objective. We assessed a risk of groundwater contamination with dimoxystrobin based on mathematical modeling and experimental study of its vertical migration in the "soil - groundwater" system and a scientific substantiation of the threshold concentration in soil by water-migration index of the risk for the further development of maximum allowable concentration (MAC) in soil.

Materials and methods. A forecast of the risk of groundwater contamination with dimoxystrobin was conducted on the basis of the determination of the integral risk vector, proceeding from the index of leaching potential, period of substance half-destruction due to a hydrolysis and a zone of biological action. During the mathematical modeling of dimoxystrobin migration from soil into groundwater we used the regression equations, describing a dependence of the hygienic standards in soil from the MAC in water reservoirs. Experimental study of dimoxystrobin vertical migration was performed on 6 filtration $\mathrm{col}$ umns, designed by Acad. E.I Honcharuk, with a use of the model soil reference № 1 and leached black earth. Initial concentrations of dimoxystrobin in the upper $(0.2 \mathrm{~m}$ ) layer of soil made up 0.05; 0.1;0.5 and $1.0 \mathrm{mg} / \mathrm{kg}$. During the first 30 days sample selection of filtrate was performed daily, then - every by the method of high-performance liquid chromatography with a limit of quantitative determination of $0.001 \mathrm{mg} / \mathrm{dm}^{3}$.

Results. Dimoxystrobin has a low or medium mobility by the rate of organic carbon adsorption coefficient but a high ability to migration from soil into groundwater by the index of the potential elution. The tentative allowable concentration (TAC) of dimoxystrobin in the soil, calculated by the regression equations, made up $0.04 \mathrm{mg} / \mathrm{kg}$, it was half as many as the TAC approved in Ukraine. Integral vector of the risk for the health of the population due to the groundwater contamination with dimoxystrobin complies with a high level( 138,6 points). Dimoxystrobin was established experimentally to be extremely mobile in the "soil-groundwater" system. Migration levels of dimoxystrobin from soil to filtrate depend on the type of the surface arable layer and the initial concentrations of the substance. The threshold dimoxystrobin concentration in soil by water-migration risk coefficient was determined on the level of $0.05 \mathrm{mg} / \mathrm{kg}$, which corresponded to 1.5 maximum rates of application. Therefore, a use of the preparations, based on dimoxystrobin in a maximum recommended rate of application, will not cause a contamination of groundwater under the real soil-and-climatic conditions of Ukraine.

\section{Keywords: fungicides, dimoxystrobin, groundwater contamination, threshold concentration, risk assessment.}

підземні води внаслідок міграції із ґрунту.

Для прогнозу небезпечності для здоров'я населення забруднення підземних вод внаслідок вертикальної міграції дімоксистробіну із ґрунту проведене визначення інтегрального вектора небезпечності за методикою Сергєєва С.Г. зі співавт. [9]. Бальна оцінка індексу потенційного вимивання (GUS = 3,05), періоду напівруйнації внаслідок гідролізу у воді $\left(\tau_{50}>100\right.$ діб) та зони біологічної дії $\left(Z_{\text {biol.ef. }}=1250\right)$ становить по 80 балів для кожного критерію. Інтегральний вектор, розрахований згідно з формулою (2), становить 138,6 та свідчить про високий рівень небезпечності для здоров'я забруднення ґрунтових вод дімоксистробіном і необхідність обов'язкового врахування процесу його міграції у системі «ґрунт - ґрунтові води» при обґрунтуванні гігієнічного нормативу у ґрунті для попередження забруднення джерел децентралізованого водопостачання. На жаль, чинна в Україні методика розрахункового обґрунтування гігієнічного нормативу пестицидів у ґрунті [12], згідно з якою обґрунтовано ОДК дімоксистробіну на рівні 0,08 мг/кг, не враховує зазначений шлях міграції.

Перед проведенням експериментальних досліджень нами на підставі рівнянь (3-6), які описують залежність між ГДК речовини у ґрунті у разі її обґрунтування за лімітуючим водно-міграційним показником шкідливості та ГДК у воді водойм, розраховані орієнтовно допустимі концентрації дімоксистробіну у ґрунті: 0,$25 ; 0,25 ; 0,12$ та 0,08 мг/кг відповідно. Для підвищення надійності нормативу, обґрунтованого на підставі рівнянь

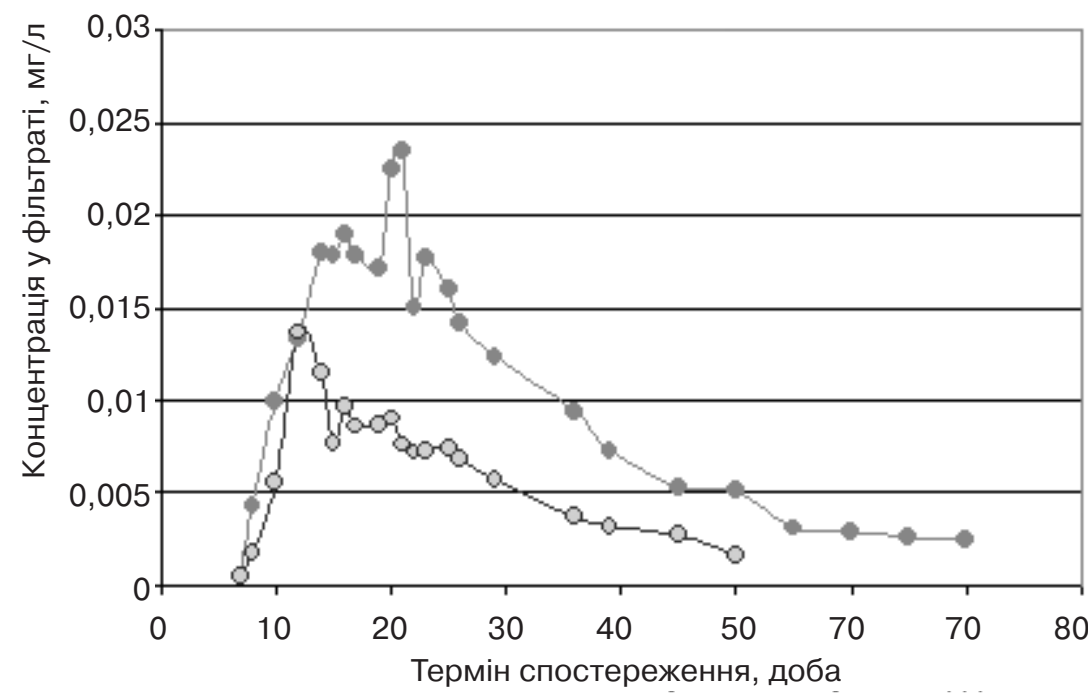

$\longrightarrow$ МГЕ №1

(3-5), як ОДК рекомендовано обирати найменшу з розрахованих величин, тобто 0,12 мг/кг, а також враховувати 3 коефіцієнти запасу [13]. Зважаючи на те, що дімоксистробін є високостабільним у ґрунті, $\mathrm{K}_{1}$ вважається рівним 3. Оскільки при вивченні вилуговування дімоксистробіну 3 радіоактивною міткою 94,2103,3\% загальної радіоактивності визначали у верхніх 18 см

Рисунок 
колони [5] і за глибиною міграції, згідно з [7], його можна віднести до III класу небезпечності, то $\mathrm{K}_{2}$ дорівнює 1. Оскільки метаболіти, які утворюються у ґрунті через руйнацію дімоксистробіну, не $є$ стабільнішими за вихідну речовину і малотоксичними, то $\mathrm{K}_{3}$ дорівнює 1. Тоді ОДК дімоксистробіну у ґрунті згідно з [13] становить 0,04 мг/кг. Відповідно до [14] для підвищення надійності нормативу, обґрунтованого на підставі рівняння (6) - 0,08 мг/кг, вводиться коефіцієнт запасу 2, тобто ОДК також становить 0,04 мг/кг. Таким чином, концентрація дімоксистробіну, яка утвориться у ґрунтовій воді внаслідок його вертикальної міграції із ґрунту, не перевищуватиме $0,003 \mathrm{мг/д^{3 }}$ за його вмісту у ґрунті на рівні 0,04 мг/кг і нижче, що не було враховано під час обґрунтування затвердженої в Україні ОДК у ґрунті.

При експериментальному вивченні процесу міграції дімоксистробіну із ґрунту у фільтрат встановлено, що інтенсивність і тривалість міграції речовини у ґрунтовий потік залежить від його вихідної концентрації у поверхневому шарі ґрунту (табл. 1). Максимальний вміст пестициду у фільтраті за вихідної концентрації у МГЕ № 1 0,05 мГ/КГ становить

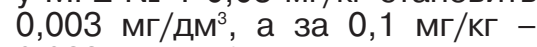

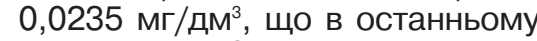
випадку у 7,8 разів перевищує ГДК у воді водойм $(0,003$ мг/дм³). Вказані максимальні концентрації відзначені на 12 і 21 добу відповідно. Вміст дімоксистробіну у фільтраті за вихідної концентрації 0,05 мг/кг вже на 25 добу нижчий за межу кількісного визначення (MKB) 0,001 дм ${ }^{3}$, тоді як за $0,1 \mathrm{Mг/Кг} \mathrm{на} 70$ добу у 2,5 рази перевищує МКВ.

у чорноземі вилуженому за вихідних концентрацій дімоксистробіну у ґрунті 0,$05 ; 0,1 ; 0,5$ і 1,0 мг/кг максимальний вміст речовини у фільтраті становить 0,$0026 ; \quad 0,0137 ; \quad 0,0228$

\section{Баланс дімоксистробіну у системі "ґрунт - ґрунтові води"}

\begin{tabular}{|l|c|c|c|c|c|c|}
\hline \multirow{2}{*}{\multicolumn{1}{|c|}{ Показник }} & \multicolumn{5}{|c|}{$\begin{array}{c}\text { Тип ґрунту і вихідний вміст } \\
\text { дімоксистробіну у поверхневому } \\
\text { (20 см) шарі ґрунту (мг/кг) }\end{array}$} \\
\cline { 2 - 8 } & \multicolumn{2}{|c|}{ МГЕ № 1 } & \multicolumn{2}{|c|}{ Чорнозем вилужений } \\
\cline { 2 - 8 } & 0,05 & 0,1 & 0,05 & 0,1 & 0,5 & 1,0 \\
\hline $\begin{array}{l}\text { Кількість дімоксистробіну, } \\
\text { яку внесено у колону, мг }\end{array}$ & 2,5 & 5 & 2,5 & 5 & 25 & 50 \\
\hline $\begin{array}{l}\text { Кількість дімоксистробіну, } \\
\text { яку знайдено у фільтраті, мг }\end{array}$ & 0,154 & 2,338 & 0,122 & 1,058 & 2,611 & 7,252 \\
\hline \% до внесеного у колону & 6,2 & 46,8 & 4,9 & 21,2 & 10,4 & 14,5 \\
\hline
\end{tabular}

0,0661 мг/дм³ відповідно, що у трьох останніх випадках у 4,6; 7,6 і 22,0 рази вище за ГДК у воді водойм. Вказані максимальні концентрації було відзначено на 14, 12, 21 і 20 добу відповідно. Вміст дімоксистробіну у фільтраті за вихідної концентрації 0,05 мг/кг вже на 26 добу нижчий за МКВ, тоді як за 0,5 мг/кг на 70 добу у понад 10 разів перевищує МКВ.

Інтенсивніше і триваліше дімоксистробін мігрує із МГЕ № 1 (рис.). За вихідної концентрації у ґрунті 0,1 мг/кг максимальний вміст речовини у фільтраті становить у разі МГЕ № 1 0,0235 мг/дм³ ${ }^{3}$ чорнозему вилуженого - 0,0137 мг/дм³ рази нижче (табл. 1). При цьому на 50 добу надходження у фільтрат із МГЕ № 1 становить 0,0051 $\mathrm{Mr} /$ дм $^{3}$, а із чорнозему вилуженого - 0,0016 мг/дм ${ }^{3}$, тобто у 3,2 рази менше.

Наведені дані свідчать про надзвичайну рухливість дімоксистробіну у системі «ґрунт - ґрунтові води». Більшу мобільність дімоксистробін демонструє у МГЕ № 1 (табл. 2). Так, за однакової початкової концентрації дімоксистробіну у ґрунті 0,1 мг/кг у результаті міграції із МГЕ № 1 сумарна кількість речовини, виявлена у фільтраті, становить 2,338 мг, або $46,8 \%$ від внесеної у колону кількості, а у випадку чорнозему вилуженого - 1,058 мг, або 21,2\%. Загалом у діапазоні вихідних концентрацій 0,05-0,1 мг/кг із МГЕ № 1 до фільтрату переходить 6,2-46,8\%, із чорнозему вилуженого за концентрацій 0,05-1,0 мг/кг - 4,9-21,2\% вихідної кількості речовини відповідно. Отже, дімоксистробін $€$ надзвичайно рухомим у системі «ґрунт - ґрунтові води» і у разі МГЕ № 1 з низькою сорбційною здатністю, і у разі чорнозему вилуженого.

Таким чином, тільки за вихідної концентрації дімоксистробіну у поверхневому шарі ґрунту 0,05 мг/кГ, яка відповідає 1,5

Таблиця 2

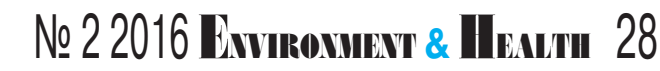

максимальним нормам витрат (0,1 кг д.р./га), вміст речовини у фільтраті не перевищив величину ГДК у воді водойм 0,003 мг/дм ${ }^{3}$.

Отримані нами результати добре кореспондуються 3 даними літератури. Так, Агенція з охорони навколишнього середовища США (EPA US) для оцінки потенційного ризику для здоров'я при споживанні води, яка забруднена пестицидами внаслідок міграції із ґрунту, широко застосовує модель SCI-GROW (скринінг концентрації у ґрунтових водах) [17, 18]. SCl-GROW оцінка враховує швидкість деградації речовини у ґрунті, коефіцієнт сорбції $\mathrm{K}_{\text {ос }}$, норму витрат, кратність застосування пестициду протягом вегетаційного сезону та показує максимально можливу концентрацію сполуки у ґрунтових водах (мкг/дм ${ }^{3}$ ) за норми витрат 1 кг(л)/га. Згідно 3 [6] зазначений показник для дімоксистробіну становить 3,59410-01 мкг/дм³ ${ }^{3}$ К Крім того, математичне моделювання, проведене з урахуванням $\tau_{50}$ дімоксистробіну 82,5 діб, показало, що концентрація вихідної речовини у ґрунтовій воді не перевищить

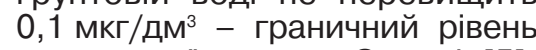
для питної води в Європі [5]. Зазначене було підтверджено результатами лізиметричних досліджень, проведених у $\mathrm{Hi}$ меччині [5].

\section{1. Висновки}

1. Дімоксистробін - діюча речовина препарату Піктор, КС є високостійким у воді та ґрунті (1 клас небезпечності згідно з ДСанПіН 8.8.1.002-98), відрізняється низькою або середньою мобільністю за величиною коефіцієнта сорбції органічним вуглецем $\left(\mathrm{K}_{\mathrm{oc}}\right)$, але високою здатністю до міграції із ґрунту у підземні води за індексом потенційного вимивання (GUS). Високий рівень небезпечності для здоров'я населення ґрунтових вод, які забруднені дімоксистробіном внаслідок його міграції із ґрунту, підтверджує інтегральний вектор небезпечності - 138,6.

2. Дімоксистробін за результатами експериментального вивчення процесу вертикальної міграції $€$ надзвичайно рухливим у системі «ґрунт - ґрунтові води». Рівні його міграції із ґрунту у фільтрат залежать від типу поверхневого орного шару та вихідних концентрацій речовини. За однакових інших умов із МГЕ № 1 дімоксистробін мігрує більшою мірою, ніж із чорнозему вилуженого. 
3. Порогова концентрація дімоксистробіну у ґрунті за водно-міграційним показником шкідливості, яка була визначена в екстремальних ґрунтово-кліматичних умовах, становить 0,05 мг/кг і гарантує дотримання затвердженого гігієнічного нормативу дімоксистробіну у воді водойм $\left(0,003 \mathrm{мг} /\right.$ дм $\left.^{3}\right)$.

4. Використання препарату Піктор, КС на основі дімоксистробіну у рекомендованій максимальній нормі витрат 0,5 л/га не призведе до забруднення ґрунтових вод у ґрунтово-кліматичних умовах України.

ЛІТЕРАТУРА

1. Монарх В.В. Оцінка екологічних ризиків забруднення пестицидами компонентів агроекосистеми / В.В. Монарх // Збалансоване природокористування. - 2014. № 1. - С. 206-212.

2. Динаміка залишкових кількостей пестицидів у водах сільськогосподарського призначення в умовах Полтавщини / В.В. Коваль, В.О. Наталочка, С.К. Ткаченко, О.В. Міненко // Вісник Полтавської державної аграрної академії. - 2011. № 1. - C. 22-26.

3. Семчук Ю.С. Геостатичний аналіз забруднення ґрунтових вод за даними спостережень якості колодязної води регіону / Ю.С. Семчук, А.Р. Ящолт // Вісник Вінницького політехнічного інституту. - 2013. - № 3. C. 17-21.

4. Understanding the strobilurin fungicides / D.W. Bartett, G.M. Clough, C.R.A. Godfrey et al. // Pesticide Outlook. - 2001. № 12. - P. 143-148.

5. Conclusion regarding the peer review of the pesticide risk assessment of the active substance dimoxystrobin: EFSA Scientific Report. - 2005. № 46. - P. 1-82.

6. Димоксистробин: основная информация о пестициде [Электронный ресурс]: PPDB: Pesticide Properties Data Base. Режим доступа: http://rupest.ru /ppdb/dimoxystrobin.html.

7. Пестициди. Класифікація за ступенем небезпечності :

ДСанПіН 8.8.1.002-98 // Зб.

важливих офіційних матеріалів 3 санітарних і протиепідемічних питань. - Київ, 2000. - Т. 9, ч. 1. - С. 249-266.

8. Методы оценки экологической опасности пестицидов при их регистрации (Руководство по классификациям экологической опасности пестицидов) / ред. В.С. Горбатов. - Большие Вяземы, 2010. - 17 с.
9. Индикаторные критерии и прогноз опасности загрязнения подземных вод гербицидами на основе эфиров кислот / С.Г. Сергеев, А.П. Гринько, И.В. Лепешкин и др. // Современные проблемы токсикологии. - 2010. - № 2-3. - С. 76-79.

10. Гончарук Е.И. Гигиеническое нормирование химических веществ в почве: Руководство / Е.И. Гончарук, Г.И. Сидоренко. - М. : Медиіцина, 1986. - 320 с.

11. Методические рекомендации по гигиеническому обоснованию ПДК химических веществ в почве : МР № 2609-82. - М., 1982. - 57 C.

12. Методические указания по гигиенической оценке новых пестицидов: МУ № 4263-87. - К. : М-во здравоохранения УССР, 1988. - 210 с.

13. Методика розрахункового гігієнічного нормування пестицидів у ґрунті. - Київ, 2005. - 2 с. (ІнФ. лист про нововведення у системі охорони здоров'я / Укрмедпатентінформ, № 131-2005).

14. Перспективы развития гигиенического нормирования химических антропогенных соединений в почве / Е.Г. Моложанова, Л.П. Петрашенко, Т.В. Юрченко, Н.В. Колонтаева // Гиг. насел. мест. - Киев, 2001. -

Вып. 38, т. 1. - С. 247-249.

15. Методичні вказівки 3 визначення дімоксистробіну у воді методом високоефективної рідинної хроматографії: МУ № 839-2008 // Методичні вказівки з визначення мікрокількостей пестицидів у харчових продуктах, кормах та навколишньому середовищі. - Київ, 2011. - № 74. - С. 84-97.

16. Наземцева Я.О. Моделювання міграції пестицидів у ґрунтах від джерел постійного забруднення / Я.О. Наземцева, Д.О. Лазненко // ВосточноЕвропейский журнал передовых технологий. - 2013. - № 4/10 (64). - C. 12-15.

17. Cohen S. Recent examples of pesticide assessment and regulation under FQPA / $\mathrm{S}$. Cohen // Agricultural chemical news. - 2000. - Vol. 20 (1). P. 41-43.

18. Cohen S. Successful evaluation of EPA's new screening model / S. Cohen // Agricultural chemical news. - 1998. - Vol. 18 (4). - P. 55-57.

REFERENCES

1. Monarkh V.V. Zbalansovane pryrodokorystuvannia. 2014 ; 1 : 206-212 (in Ukrainian).

2. Koval V.V., Natalochka V.O., Tkachenko S.K., Minenko O.V.
Visnyk Poltavskoi derzhavnoi ahrarnoi akademii. 2011; 1 : 2226 (in Ukrainian).

3. Semchuk Yu.S., Yashcholt A.R. Visnyk Vinnytskoho politekhnichnoho instytutu. 2013 ; 3 : 17-21 (in Ukrainian).

4. Bartett D.W., Clough G.M., Godfrey C.R.A., Godwin J.R., Hall A.A., Heaney S.P. Maund S.J. Pesticide Outlook. $2001 ; 12$ : 143-148.

5. Conclusion Regarding the Peer Review of the Pesticide Risk Assessment of the Active Substance Dimoxystrobin: EFSA Scientific Report. 2005 ; 46 : 1-82.

6. Dimoksistrobin: osnovnaia informatsiia o pestitside [Dimoxystrobin: Main Information on Pesticide] : PPDB: Pesticide Properties Data Base. Available at : http://rupest.ru/ppdb/dimoxystrobin.html (in Russian).

7. Pestytsydy. Klasyfikatsiia za stupenem nebezpechnosti : DSanPiN 8.8.1.002-98 [Pesticides. Classification by the Degree of Danger : National Sanitary Rules and Norms 8.8.1.002-98]. In : Zbirnyk vazhlyvykh oficiinykh materialiv z sanitarnykh i protyepidemichnykh pytan [Collection of the Important Official Materials on Sanitary and Anti-Epidemic Issues]. Kyiv ; 2000 ; 9 (1) : 249-266 (in Ukrainian). 8. Gorbatov V.S. (ed.) Metody otsenki ekologicheskoi opasnosti pestitsidov pri ikh registratsii (Rukovodstvo po klassifikatsiiam ekologicheskoi opasnosti pestitsidov) [Methods for the Assessment of the Ecological Danger of the Pesticides at their Registration (Guides on the Classification of the Ecological Danger of Pesticides]. Bolshie Viazemy (Russia) ; 2010 : 17 p. (in Russian).

9. Sergeev S.G., Grinko A.P., Lepeshkin I.V., Kolontaeva N.V. Sovremennye problemy toksikologii. 2010 ; 2-3 : 76-79 (in Russian).

10. Goncharuk E.I., Sidorenko G.I. Gigienicheskoe normirovanie khimicheskikh veshchestv v 
pochve: rukovodstvo [Hygienic Standardization of the Chemical Substances in Soil : Manual]. Moscow : Meditsina ; 1986 : 320 p. (in Russian).

11. Metodicheskie rekomendatsii po gigienicheskomu obosnovaniiu PDK khimicheskikh veshchestv $v$ pochve [Methodical Recommendations on the Hygienic Substantiation of the MAC of Chemical Substances in Soil] : MR № 2609-82. Moscow 1982 : 57 p. (in Russian).

12. Metodicheskie ukazaniia po gigienicheskoi otsenke novykh pestitsidov [Methodical Instructions on the Hygienic Assessment of the New Pesticides] : MU № 4263-87. Kiev ; 1988 : 210 p. (in Russian).

13. Metodyka rozrakhunkovoho hihiienichnoho normuvannia pestytsydiv u hrunti [Methodology for the Calculation Hygienic Standardization of the Pesticides in Soil]. Kyiv ; 2005 ; 2 p. [Information Letter № 131-2005 on the Innovations in the System of Public Health / Ukrmedpatentinform].

14. Molozhanova E.G., Petrashenko L.P., Yurchenko T.V., Kolontaeva N.V. Perspektivy razvitiia gigienicheskogo normirovaniia khimicheskikh antropogennykh soedinenii v pochve [Prospects in the Development of the Hygienic Standardization of the Chemical Anthropogenic Compounds in Soil]. In : Gigiena naselennykh mest [Hygiene of Settlements]. Kiev ; 2001 ; 38(P.1) : 247-249 (in Russian).

15. Metodychni vkazivky z vyznachennia dimoksystrobinu u vodi metodom vysokoefektyvnoi ridynnoi khromatohrafii : MU № 839-2008 [Methodical Instructions for the Determination of Dimoxystrobin in Water by the Method of High-Efficient Liquid Chromatography : MU № 8392008]. In : Metodychni vkazivky z vyznachennia mikrokilkostei pestytsydiv $\mathrm{v}$ kharchovykh produktakh, kormakh ta navkolyshnomu seredovyshchi [Methodical Instructions for the Determination of Microquantities of the Pesticides in Food Products, Forage and Environment]. Kyiv ; 2011; 74 : 84-97 (in Ukrainian).

16. Nazemtseva Ya.O., Laznenko D.O. Vostochno-evropeiskii zhurnal peredovykh tekhnologii. 2013 ; 4/10 (64) : 12-15 (in Russian).

17. Cohen S. Agricultural Chemical News. 2000 ; 20 (1) : 41-43.

18. Cohen S. Agricultural Chemical News. 1998 ; 18 (4) : 55-57.

Надійшла до редакції 01.02.2016.
PROGNOSTICATION OF AIR POLLUTION EFFECT ON THE MORBIDITY OF THE POPULATION IN THE INDUSTRIAL CITY Hrebniak M.P., Fedorchenko R.A.

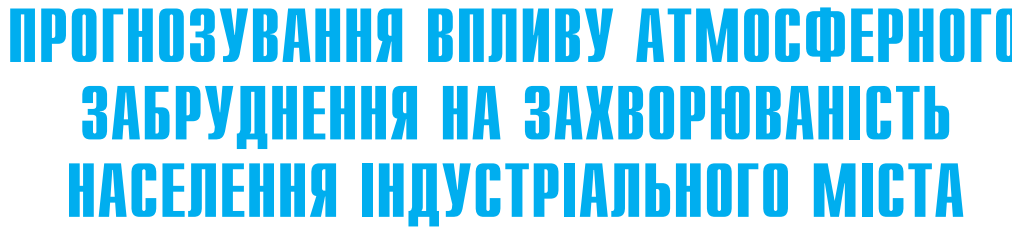

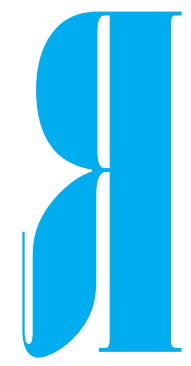

ГРЕБНЯК М.П. ФЕДОРЧЕНКО Р.А.

Запорізький державний медичний університет

УдК: $613.15: 614.71 / .72$ 616-02-037: $614.78(1-31)$

Ключові слова: атмосферні забруднення, захворюваність, хвороби органів дихання, покроково-регресійні моделі. кість довкілля, передусім атмосферного повітря, зумовлює стан здоров'я населення індустріальних міст. Провідним принципом Європейського законодавства про якість повітря є оцінка рівнів його забруднення 3 використанням емпіричного моделювання [1-3]. У зв'язку з цим до актуальних проблем належить об'єктивізація оцінки якості повітря та впливу на здоров' я населення специфічних забруднювачів [4, 5].

Актуальність проблеми. Забруднення атмосферного повітря суттєво впливає на здоров'я людей, адже дихання - це основа життєдіяльності будь-якого організму. Внаслідок постійних та повторюваних впливів на людину через повітря вони здатні змінити якість життя та стан здоров'я населення навіть до

ПРОГНОЗИРОВАНИЕ ВЛИЯНИЯ ЗАГРЯЗНЕНИЯ

АТМОСФЕРНОГО ВОЗДУХА НА ЗАБОЛЕВАЕМОСТЬ НАСЕЛЕНИЯ ИНДУСТРИАЛЬНОГО ГОРОДА

Гребняк Н.П., Федорченко Р.А.

Запорожский государственный медицинский университет

Цель работы: обосновать модели прогнозирования влияния промышленных выбросов на заболеваемость населения. Материалы и методы исследования. Валовые выбросы в атмосферный воздух мегаполиса, показатели заболеваемости населения, коррелляционно-регрессионный анализ.

Результаты и их обсуждение. Установлен характер зависимости промышленных выбросов от уровня использования мощностей производства. Обоснованы пошагово-

регрессионные модели прогнозирования заболеваемости органов дыхания с учетом характера атмосферных загрязнений. Для заболеваемости и распространенности болезней органов дыхания приоритетными являются объемы выбросов в атмосферный воздух аммиака, стирола, фенола, серной и азотной кислот, сероводорода, толуола; из концентраций прогностически значимыми являются фенол, диоксид азота, хлориды и фториды водорода. Практическая апробация разработанных моделей для взрослых и детей свидетельствует о наличии очень высокой взаимосвязи с выбросами и указывает на высокую достоверность прогнозирования заболеваемости $(87,7-91,6 \%, p<0,05)$.

\section{Ключевые слова: атмосферные загрязнения, заболеваемость, болезни органов дыхания, пошагово-регрессионные модели.}

( Гребняк М.П., Федорченко Р.А. СТАТТЯ, 2016 